\title{
MENINGKATKAN KREATIVITAS ANAK USIA DINI MELALUI KEGIATAN SENI PATUNG DARI BAHAN GIPS
}

\author{
Anisa Suciati Wardhani, Euis Kurniati, I Gusti Komang Aryaprasetya \\ Universitas Pendidikan Indonesia, Jln. Setiabudhi no. 229 Bandung
}

\begin{abstract}
Abstrak : Meningkatkan Kreativitas Anak Usia Dini Melalui Kegiatan Seni Patung dari Bahan Gips. Penelitian ini di latar belakangi oleh suatu permasalahan dimana perkembangan kreativitas pada anak di TK Pelangi belum berkembang secara optimal. Hal ini disebabkan oleh kegiatan seni di TK Pelangi belum dirasa optimal. Intensitas dalam kegiatan seni mematung pun masih sangat jarang, media untuk mengekspresikannya masih dalam dua dimensi yaitu berupa gambar. Daya imajinasi anak yang sedang berkembang harus pula disertai dengan media ekspresi yang optimal. Salah satu alternatif dengan media yang berbeda seperti Gips yang mempunyai sifat lentur dan bertekstur diharapkan dapat menjadikan proses berkarya lebih mengasikkan sehingga kreativitas membentuk patung lebih berkembang. Untuk meningkatkan kreativitas anak dalam kegiatan seni mematung dipilihlah bahan gips sebagai media ekspresinya. Gips akan menjadi bahan baru untuk anak mempunyai pengalaman mengenal tekstur. Kegiatan ini juga bertujuan untuk menumbuhkan sensitivitas keindahan dan nilai seni bagi anak sejak usia dini. Penelitian ini menggunakan metode PTK, subjek penelitiannya yaitu, Kelas A di TK Pelangi Baleendah. Anak Kelas A diberi pembelajaran seni mematung dengan bahan gips. Adapun data yang akan diperoleh merupakan hasil observasi, dokumentasi, dan tes. Hasil penelitian menunjukan bahwa berdasarkan tindakan yang diberikan kepada anak, maka terdapat peningkatan yang signifikan dari pembelajaran seni mematung dari bahan gips sebelum dan sesudah diterapkan pembelajaran. Hasil setelah diberikan kegiatan seni mamatung dengan bahan gips menghasilkan skor lebih baik dibandingkan sebelum diberikan kegiatan seni mamatung dengan bahan gips.
\end{abstract}

Kata Kunci : Kreativitas, Anak usia dini, Seni patung, Gips.

$\begin{array}{lrrrr}\text { Dalam kehidupan sehari-hari sering } & \text { kreativitasnya bagi kehidupan yang } \\ \text { dijumpai anak yang aktivitas fisiknya } & \text { bermakna (Suratno, 2005, hlm. 23). } \\ \text { berlebihan dengan menendang bola, } & \text { Pada umumnya anak yang kreatif } \\ \text { memanjat pohon, mengganggu teman yang } & \text { selalu ingin tahu, memiliki minat yang luas, } \\ \text { sedang bermain, dan sebagainya tanpa } & \text { dan menyukai kegemaran dan aktivitas yang } \\ \text { tujuan yang jelas. Ada juga anak yang } & \text { kreatif. Dalam hal aktivitas belajar, anak } \\ \text { pendiam, enggan beraktivitas tanpa disuruh } & \text { kreatif menunjukkan sikap kemandirian dan } \\ \text { orang tuanya atau gurunya. Tetapi sering } & \text { percaya diri yang baik. Banyak aktivitas } \\ \text { juga ditemukan anak yang banyak idenya, } & \text { kreatif yang dapat diciptakan oleh guru } \\ \text { banyak akalnya, banyak caranya dalam } & \text { dalam menstimulasi perkembangan anak. } \\ \text { menghadapi suatu masalah. Kelompok anak } & \text { Baik itu aktivitas kognitif, fisik motorik, } \\ \text { yang terakhir ini kelak dapat diharapkan } & \text { religius, bahasa dan berkesenian. Khususnya } \\ \text { menjadi individu yang kreatif dan dapat dalam aktivitas berkesenian, sebenarnya } & \text { dalan } \\ \text { mengembangkan kemampuan bakat } & \text { guru bisa lebih luwes dan bebas dalam }\end{array}$


menciptakan suasana belajar yang bisa memfasilitasi anak dalam menuangkan ideide dan gagasan kreatif anak dalam media ekspresi yang beragam pula. anak usia dini. Tetapi dalam kondisi dilapangan, guru hanya mampu memfasilitasinya dengan tidak terlalu optimal. Dalam kegiatan berkarya seni, ada yang berpendapat bahwa karya atau hasil karya hanya merupakan kendaraan agar siswa menjadi kreatif, ekspresif, sempurna, dan menyesuaikan diri.

Penilaian karya tidak ditinjau dari kriteria komponen eksternal estetik saja, seperti warna, bentuk, dan hubungannya. Penilaian keberhasilan tidak diarahkan pada unsur desain dari karya siswa, tetapi pada kreativitas anak. Penilaian keberhasilan tidak diarahkan pada unsur desain dari karya siswa, tetapi pada kreativitas anak. Karya akhir adalah penunjang proses kreatif. Proses kreatif menjadi yang utama dari seluruh pertumbuhan anak (Muharam \& Sundaryati, : 1991-1992, hlm. 28). Anak perlu difasilitasi untuk mengekspresikan daya imajinasinya yang sedang berkembang pesat ke dalam media ekspresi yang berbeda untuk mendapatkan pengalaman estetis baru untuk anak.

\section{METODE}

Metode penelitian yang digunakan yaitu Penelitian tindakan kelas (PTK) atau classroom action research. Penelitian tindakan kelas ini didesain untuk memecahkan masalah-masalah yang diaplikasikan secara langsung di dalam kelas. Penelitian yang dilakukan merupakan penelitian berbasis kelas kolaboratif, yaitu suatu penelitian yang bersifat praktis, situasional dan konteksual berdasarkan permasalahan yang muncul dalam kegiatan pembelajaran sehari-hari di Taman KanakKanak. Langkah-langkah yang ditempuh dalam penelitian ini yaitu 1) Perencanaan tindakan 2) Pelaksanaan tindakan 3) Pengamatan 4) Refleksi.

Beberapa teknik pengumpulan data yang digunakan peneliti dalam upaya meningkatkan kreativitas anak kelas A di Taman Kanak-kanak Pelangi melalui kegiatan seni patung dari bahan gips dilakukan dengan tiga teknik penelitian yaitu observasi, wawancara dan dokumentasi. Adapun langkah-langkah pelaksanaan analisis data adalah sebagai berikut :

1. Reduksi Data

Reduksi data adalah proses pengumpulan data selama proses Penelitian. Adapun data yang akan dikumpulkan dalam Penelitian ini mencakup :

a. Profil kreativitas anak kelompok A

b. Kegiatan seni patung menggunakan bahan gips

c. Hasil wawancara dengan guru kelas, catatan lapangan dan dokumentasi kegiatan.

\section{Penyajian Data}

Data yang telah diperoleh kemudian disajikan dalam bentuk table, grafik dan bentuk deskriptif. Adapun penyajian data tersebut terdiri dari :

a. Tabel hasil analisis kreativitas anak keloompok A

b. Grafik perkembangan berbicara anak

c. Grafik hasil Penelitian tindakan

d. Deskripsi hasil wawancara, catatan lapangan, aktivitas guru dan dokumentasi kegiatan.

\section{HASIL DAN PEMBAHASAN}

Profil Kreativitas Anak Kelompok A Di Taman Kanak-kanak Pelangi Sebelum Diterapkannya Kegiatan Seni Patung Dari Bahan Gips. 
Untuk mengetahui profil awal mengenai kreativitas anak kelompok A sebelum diterapkannya kegiatan seni patung dari bahan gips, maka peneliti mencari datadata atau informasi yang akurat dari sumber yang terpercaya yaitu melalui pengamatan langsung dan proses wawancara terhadap guru kelas yang lebih dulu memahami kondisi anak didiknya yang dilaksanakan pada tanggal 12 Mei 2015 sampai tanggal 16 Mei 2015.

Adapun data awal yang diperoleh saat berlangsungnya proses prasiklus yaitu anak pada dasarnya sudah mempunyai daya kreatif dan imajinasi yang sedang berkembang pesat, tetapi dalam mengeksperikan imajinasinya dalam bentuk tiga dimensi masih kurang di fasilitasi secara optimal ini terlihat dari kegiatan pembelajaran dimana media ekspresi yang digunakan masih dalam bentuk dua dimensi seperti kertas. Kegiatan yang kurang beragam yang hanya mengacu dan terbiasa dengan kegiatan dengan mewarnai majalah, menggambar, buku keterampilan yang dominan pada aktivitas ditempat duduk dengan lembar kerja mewarnai, mencocok, menebalkan huruf, mencocok pola, dsb. Sementara daya imajinasi anak yang sedang berkembang harus pula difasilitasi oleh guru secara optimal dan variatif pula. Semangat, antusiasme, daya imajinasi, daya kreatif dan kemampuan emas anak lainnya seyogyanya dimanfaatkan untuk menanamkan berbagai nilai positif, pengalaman estetika dalam berkarya, dan stimulasi kreatif lainnya sehingga anak dapat berkembang secara optimal. Guru berperan penting untuk memfasilitasi dan mempersiapkan kegiatan yang bermakna, bernilai positif, dan dapat mengembangkan berbagai aspek perkembangan anak.

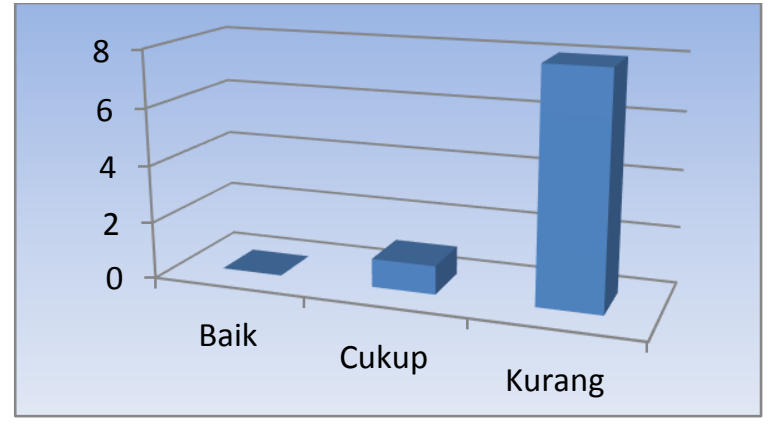

\section{Grafik 1. Persentase kreativitas pada prasiklus}

\section{Penerapan Kegiatan Seni Patung dari Bahan Gips untuk Meningkatkan Kreativitas Anak Kelompok A di Taman Kanak-kanak Pelangi Baleendah}

Berdasarkan data hasil Penelitian pada pra siklus, yaitu persentase keberhasilan masih kurang dari $45 \%$ yang berada pada ketegori K (kurang). Peneliti dan guru masih mengharapkan peningkatan yang lebih signifikan di atas $45 \%$ yang berada dalam kategori B (Baik). Sehingga anak sudah dapat kesempatan dalam mengapresiasi imajinasinya ke dalam media ekspresi yang lebih nyata. Untuk pelaksanaan kegiatan pembelajaran dilakukan dalam dua siklus, setiap siklus terdiri dari dua tindakan. Masing-masing tindakan terdapat tahap perencanaan, pelaksanaan, dan observasi, serta melakukan refleksi.

Peningkatan Kreativitas Anak Melalui Kegiatan Pembuatan Patung Gips dengan Bahan Gips pada Kelompok A TK Pelangi

Peningkatan kreativitas anak kelompok A TK Pelangi setelah diterapkannya kegiatan pembuatan patung gips dari bahan gips ini menunjukkan adanya peningkatan disetiap siklusnya, proses pembelajaran melalui kegiatan pembuatan patung ini dapat 
meningkatkan kreativitas anak. Disamping membantu anak dalam meningkatkan kreativitas, kegiatan pembuatan patung gips ini juga mengajarkan anak juga dalam pengukuran, penakaran, bertanggung jawab, fokus, karena dalam kegiatan pembuatan patung ini anak dilatih untuk memahami setiap proses (tahapan) pembuatan patung gips. Kondisi pembelajaran yang menyenangkan dan bermakna membantu guru mencapai tujuan pembelajaran dan peneliti dalam menerapkan kegiatan pembuatan patung gips ini sehingga anak dapat menikmati kegiatannya.

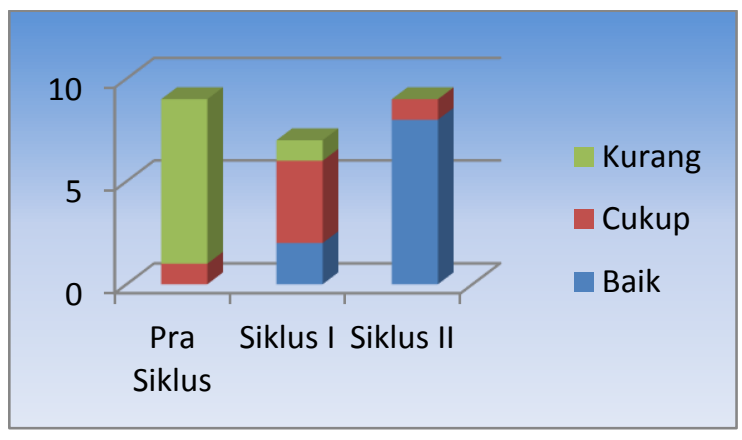

\section{Grafik 2. Persentase Peningkatan} Kreativitas

Berdasarkan hasil penelitian yang telah dilakukan mulai dari tanggal 12 mei 2015 sampai tanggal 30 Mei 2015, dalam rangka meningkatkan kreativitas anak kelompok A Taman Kanak-Kanak Pelangi Kabupaten Bandung, maka ada tiga hal yang harus dibahas secara lebih detal oleh peneliti, diantaranya : 1) faktor yang menjadi penyebab kurang optimalnya pengembangan kegiatan dalam meningkatkan kreativitas anak kelompok A Taman Kanak-kanak Pelangi ( profil kreativitas) 2) bagaimana penerapan kegiatan seni patung dari bahan gips dan 3) bagaimana peningkatan kreativitas anak kelompok A Taman Kanakkanak Pelangi Baleendah setelah ditetapkannya kegiatan tersebut. Berikut ini akan peneliti uraikan secara lebih rinci.

Profil kreativitas anak kelompok A Taman Kanak-kanak Pelangi Baleendah sebelum diterapkannya Kegiatan Seni Patung dari bahan Gips.

Berdasarkan hasil observasi dan studi dokumentasi yang telah peneliti lakukan secara bertahap, terstruktur dan berkelanjutan mengenai profil kreativitas anak kelompok A TK Pelangi sebelum diterapkannya kegiatan pembuatan patung menggunakan bahan gips kreativitas anak dalam keadaan kurang optimal. Banyak faktor yang mempengaruhi kurang optimal nya perkembangan kreativitas anak. Beberapa faktor-faktor yang jadi hambatan dalam pengembangan kreativitas anak kelompok A Taman Kanak-kanak Pelangi adalah 1)media ekspresi anak yang kurang mampu menstimulasi kreativitas anak secara keseluruhan, 2) hambatan dari pihak gurunya sendiri kurang bisa memfasilitasi melalui kegiatan pembelajaran yang menarik minat anak.

Upaya penerapan kegiatan seni patung dari bahan gips untuk meningkatkan kreativitas anaka kelompok A Taman Kanak-kanak Pelangi Baleendah

Kegiatan Pembuatan Patung Gips Untuk Meningkatkan Kreativitas Anak pada Kelompok A TK Pelangi dalam penelitian ini dilaksanakan dengan menggunakan dua siklus dan masing-masing siklus terdapat dua tindakan dengan tambahan tindakan prasiklus. Berdasarkan hasil penelitian yang sudah dilakukan sebelum tindakan, peneliti menentukan langkah-langkah pembelajaran yang akan diterapkan, yaitu tahap perencanaan, pelaksanaan, pengamatan dan 
refleksi dalam menerapkan kegiatan pembuatan patung gips untuk anak.

\section{Peningkatan Kreativitas Anak Kelompok A Taman Kanak - kanak Pelangi Baleendah setelah diterapkannya Kegiatan Seni Patung menggunakan Bahan Gips.}

Kegiatan pembuatan patung gips yang dilakukan memberikan peningkatan yang signifikan dalam mengembangkan kreativitas anak. Sejalan dengan pendapat Sumanto (2005, hlm. 22), proses berkarya seni adalah upaya pemberian pengetahuan dan pengalaman dasar kegiatan kreatif senirupa dengan menerapkapkan konsep seni sebagai alat pendidikan. Penerapan konsep seni tersebut tentunya dengan menciptakan kondisi pembelajaran yang menarik, menyenangkan di dalam suasana bermain kreatif. Berdasarkan data hasil siklus I dan II, kreativitas anak mengalami perkembangan yang signifikan. Ini disebabkan karena kegiatan pembuatan patung gips ini merupakan kegiatan yang menyenangkan untuk anak. Salah satu indikator menyenangkan untuk anak adalah anak sudah tidak memperdulikan lagi bajunya yang kotor, waktunya yang sudah habis, anak merasa kegiatan itu tanpa beban pikiran.

Berdasarkan analisis, kajian dan diskusi yang dilakukan oleh peneliti, diperlukan kegiatan alternatif untuk mengembangkan kreativitas anak yang sedang pada masa keemasannya. Salah satu media ekspresi dalam pengembangan kreativitas anak di TK bisa melalui kegiatan seni patung dari bahan gips. Gips dipilih sebagai bahan dasar pembuatan patung karena bahan ini berbeda dari biasa digunakan untuk dalam membuat patung. Berdasarkan hasil observasi mulai dari siklus I sampai II media ekspresi dan kegiatan seni yang dilakukan di TK harus beragam, ini untuk meminimalisir tingkat kebosanan anak. Menciptakan iklim sekolah yang sehat, nyaman, aman secara fisik dan psikologis anak merupakan kewajiban setiap penyelenggara pendidikan dari satuan paling kecil hingga paling tinggi sekalipun. Saat suasana sekolah dirasa nyaman oleh anak, ini akan meningkatkan semangat anak untuk belajar. Nursito (2000, hlm. 30) menyatakan, menyediakan lingkungan yang menarik akan memberikan makna yang berkesan sehingga anak akan dapat dengan bebas mengekspresikan setiap imajinasi dan kreativitas yang mereka miliki ke dalam media yang mampu menstimulasi berbagai aspek perkembangannya. Berdasarkan penjabaran hasil penelitian diatas dengan adanya peningkatan pada setiap siklusnya maka dapat disimpulkan bahwa kegiatan seni patung dari bahan gips dapat meningkatkan kreativitas anak kelas A di TK Pelangi Baleendah Bandung. Dengan demikian peneliti dapat menyimpulkan bahwa kreativitas anak kelompok A Taman Kanak-kanak Pelangi Baleendah mengalami peningkatan secara signifikan, karena persentase keberhasilan dalam pengembangan kreativias ini lebih dari $45 \%$. Sebagaimana dikemukakan oleh Munandar (2012), bahwa pengembangan kreativitas sejak usia dini, tinjauan dan Penelitianpenelitian tentang proses kreativitas, kondisi-kondisinya, serta cara yang dapat memupuk, merangsang, dan mengembangkannya menjadi sangat penting.

\section{SIMPULAN}

Pengembangan kreativitas harus dipupuk, distimulasi dan dikembangkan sejak anak berada dalam periode usia dini dimana pada masa ini potensi kreatif dan 
daya imajinasi anak sedang berkembang dengan pesat (Munandar, 2012, hlm. 3). Secara khusus kesimpulan yang dapat ditarik dari hasil Penelitian yang sudah dilakukan pada anak kelompok A Taman KanakKanak Pelangi Baleendah sebagai berikut :

1. Kondisi objektif kreativitas kelompok A TK Pelangi menunjukkan hasil kurang sesuai dengan yang diharapkan. Hal ini karena kegiatan pembelajaran yang masih menggunakan media ekspresi dua dimensi dalam kegiatan seninya, serta masih kurangnya kegiatan yang mengedepankan pengalaman estetis anak dalam berkesenian. Kegiatannya masih mencakup Paper Pencil, mewarnai, sedangkan dalam masa keemasan anak harus diberikan stimulasi positif, beragam, kreatif dan mengedepankan penuangan daya imajinasi dan kreativitas anak. Kemampuan anak dalam membuat bentuk dalam mengaplikasikan daya imajinasinya belum difasilitasi secara optimal. Diperlukan kegiatan bermain yang bisa secara keseluruhan mengembangkan aspek perkembangan anak. Beberapa faktor yang menyebabkan kurang optimalnya pengembangan kreativitas anak ini adalah dari faktor guru yang masih belum memfasilitasi anak dalam mengekspresikan imajinasinya ke dalam bentuk tiga dimensi.

2. Pelaksanaan kegiatan seni patung berbahan dasar gips sebagai salah satu upaya dalam meningkatkan kreativitas anak dilakukan dengan dua siklus yang masing-masing siklus terdiri dari dua tindakan. Pelaksaan pada siklus I tindakan I dilaksanakan pada hari selasa, 19 Mei 2015. Pada tindakan ini dipilih tema binatang karena penelitian saat tema kegiatan sudah habis dan peneliti diberi kewenangan untuk menggunakan tema tentang binatang. Pada siklus I tindakan I peneliti masih mengalami kesulitan dalam pengkondisian anak, dalam penggunaan peralatan yang digunakan untuk proses pembuatan patung. Anak masih belum mampu melakukan setiap tahapan pembuatan patung tanpa bantuan guru. Kemandirian anak dalam menyelesaikan karya patungnya masih belum terlihat perkembangannnya. Antusias anak dalam merespon setiap tahapan pembuatan patung baik sekali. Ini dikarenakan karena pada kegiatan seharihari anak kegiatan membuat patung belum pernah dilakukan. Dan ketika disuguhkan satu kegiatan yang berhubungan dengan kotor-kotoran, cat, kuas ini salah satu kegiatan menyenangkan untuk anak. Pemilihan kegiatan, media dan peralatan yang menarik akan menumbuhkan minat anak untuk melakukan kegiatan dengan baik dan optimal. Anak tidak menghiraukan bajunya yang kotor, yang anak pikirkan hanya tentang patungnya yang ingin anak beri sentuhan sesuai dengan ide, gagasannya masing-masing.

3. Kreativitas anak di kelompok A TK Pelangi setelah diterapkannya kegiatan seni patung dari bahan gips mengalami perkembangan yang signifikan. Terbukti dari hasil persentase sebelum diberikan tindakan dan setelah diberikan tindakan pada pemaparan yang telah diuraikan pada setiap siklus. Dimana sebelumnya pada pra siklus, persentase baik 0\%, cukup $11 \%$ dan baik $89 \%$. Hasil persentase pada siklus I kategori baik 29\%, kategori kurang 14\% dan kategori cukup 57\%. Pada siklus II hasil persentasenya menunjukkan kategori baik $89 \%$, kategori cukup $11 \%$ dan kategori kurang 0\%. Dapat disimpulkan 
penilaian anak dalam melakukan kegiatan tanpa bantuan ( Baik ) dari keseluruhan tindakan yang diberikan dengan persentase baik pada saat observasi sebesar 0\%, pada siklus I sebesar 29\%, dan pada siklus II sebesar 89\% pada kategori baik (B), kategori cukup (C) 11\%, dan kategori kurang (K) $0 \%$. Hal ini terjadi karena melalui kegiatan seni patung dari bahan gips anak memperoleh pengalaman estetis dalam mengeskpresikan daya imajinasi dan kreativitas anak yang sedang berkembang. Adanya kegiatan stimulasi multisensory melalui kegiatan seni patung ini membuat anak merasakan kenyamanan dan kebebasan menuangkan ide dan gagasannya secara mandiri.

\section{DAFTAR PUSTAKA}

E, Muharam \& Sundaryati, Warti. (1991). Pendidikan Kesenian II Seni Rupa. Departemen Pendidikan dan Kebudayaan :Jakarta.

Munandar, Utami. (2012) . Pengembangan Kreativitas Anak Berbakat. Jakarta : PT Rineka Cipta.

Nursito. (2000). Kiat Menggali Kreativitas. Mitra Gama Widya: Yogyakarta.

Sumanto, Drs. (2005). Pengembangan Kreativitas Senirupa Anak TK. Depatemen Pendidikan Nasional: Jakarta.

Suratno, Drs. (2005). Pengembangan Kreativitas Anak Usia Dini. Jakarta : Departemen Pendidikan Nasional. 